\title{
The response effect of pheochromocytoma (PC12) cell lines to oxidized multi-walled carbon nanotubes (o-MWCMTs)
}

\author{
Phillips $\mathrm{CL}^{1}$, Yah $\mathrm{CS}^{1}$, *Iyuke SE${ }^{1}$, Pillay $\mathrm{V}^{2}$, Rumbold $\mathrm{K}^{3}$, Choonara $\mathrm{Y}^{2}$
}

1. School of Chemical and Metallurgical Engineering, University of the Witwaterstand, Johannesburg, P/ Bag 3, Wits 2050, South Africa

2. Department of Pharmacy and Pharmacology, School of Therapeutic Sciences, University of the Witwatersrand, 7 York Road, Parktown, 2193 Johannesburg, South Africa

3. School of Molecular \& Cell Biology, University of the Witwatersrand, Johannesburg, P/Bag 3, Wits 2050, South Africa

\begin{abstract}
Background: The applications of oxidized carbon nanotubes (o-CNTs) have shown potentials in novel drug delivery including the brain which is usually a challenge. This underscores the importance to study its potential toxic effect in animals. Despite being a promising tool for biomedical applications little is known about the safety of drugs in treating brain diseases. The toxicity of oxidized multi-walled carbon nanotubes (o-MWCNTs) are of utmost concern and in most in-vitro studies conducted so far are on dendritic cell (DC) lines with limited data on PC12 cell lines.

Objectives: We focused on the effect of $o$-MWCNTs in PC12 cells in vitro: a common model cell for neurotoxicity.

Methods: The pristine multi-walled carbon nanotubes ( $p$-MWCNTs) were produced by the swirled floating catalytic chemical vapour deposition method (SFCCVD). The $p$-MWCNTs were then oxidized using purified $\mathrm{H}_{2} \mathrm{SO}_{4} / \mathrm{HNO}_{3}(3: 1 \mathrm{v} / \mathrm{v})$ and $30 \% \mathrm{HNO}_{3}$ acids to produce o-MWCNTs. The Brunauer-Emmett-Teller (BET), transmission electron microscopy (TEM), Scanning electron microscopy (SEM), thermogravimetric analyser (TGA) and Raman spectroscopy techniques were used to characterize the MWCNTs. The PC12 cells were cultured in RPMI medium containing concentrations of o-MWCNTs ranging from 50 to $200 \mu \mathrm{g} / \mathrm{ml}$.

Results: The o-MWCNTs demonstrated slight cytotoxicity at short time period to PC12 neuronal cells whilst at longer time period, no significant $(\mathrm{p}>0.05)$ toxicity was observed due to cell recovery.

Conclusion: In conclusion, the o-MWCNTs did not affect the growth rate and viability of the PC12 cells due to lack of considerable toxicity in the cells during the observed time period but further investigations are required to determine cell recovery mechanism.
\end{abstract}

Keywords: Oxidized carbon nanotubes, PC12, cellular response, toxicity Africa Health Sciences 2013; 13(4): 947 - 954 http://dx.doi.org/10.4314/ahs.v13i4.13

\section{Introduction}

Carbon nanotubes (CNTs) are molecular-scale tubes of graphitic carbon that possess excellent mechanical, magnetic and electrical properties due to their unique topology and structure. ${ }^{1,2}$. The versatility has attracted intense research in biomedical applications such as drug delivery ${ }^{3,4}$, medical imaging ${ }^{5}$, cancer treatment ${ }^{6,7}$ and the treatment of brain diseases ${ }^{8,9}$. However, toxicological information on functionalized carbon-containing particles is

\begin{tabular}{|l|}
\hline *Corresponding author: \\
Sunny Iyuke \\
School of Chemical and Metallurgical Engineering \\
University of the Witwatersrand, Johannesburg \\
P/Bag 3, Wits 2050, South Africa \\
Phone: 27117177546 \\
Fax: 27 (0) 865536435 \\
Email: sunny.iyuke@wits.ac.za \\
\hline
\end{tabular}

African Health Sciences Vol 13 Issue 4 December 2013 limited and published data on the toxic effects of CNTs are often contradictory ${ }^{10,11,12}$. The toxicity studies of both $p$-MWCNTs (un-functionalized carbon nanotubes) and $o$-MWCNTs (functionalized carbon nanotubes versatile for drug and other bioconjugates attachment) conducted so far on pheochromocytoma (PC12) cells are limited. Most of the studies are done in dendritic cells with very limited studies on PC12 cells. The PC12 cells are derived from rat adrenal medullary tumor and are widely used to study responses of differentiated neuronal cells ${ }^{13}$. The aim of this study is to study the effect on 0 -MWCNTs in PC12 cells in vitro: a common model cell for neurotoxicity. Reports by $\mathrm{Xu}$ et $\mathrm{al}^{14}$ have showed that carboxyl-terminated MWCNTs can suppress potassium channel activities in PC12 cells in a time dependent and irreversible manner. Other reports by Wang et $\mathrm{al}^{15}$ found a 
decrease in cell viability of PC12 cells due to single walled CNTs (SWCNTs) expressing oxidative stress. Using other cell lines, Zhang et $\mathrm{al}^{16}$ showed that acid treated MWCNTs and SWCNTs have an increased cytotoxic effect in human cervical carcinoma HeLa cells when compared to the untreated CNTs (pristine CNTs). Also Bottini and colleagues ${ }^{17}$ compared the toxicity of pristine MWCNTs to o-MWCNTs on human $\mathrm{T}$ lymphocyte cells. They found that $o$ MWCNTs were more toxic than $p$-MWCNTs, with the formal inducing loss of cell viability through apoptosis at dosses of $400 \mu \mathrm{g} / \mathrm{ml}$.

\section{Methods}

\section{Chemicals and reagents}

The ferrocene, sulphuric and nitric acid, methanol, diethyl ether and ethanol were obtained from Merck Chemicals (Pty) Ltd, South Africa. The argon and acetylene gases were obtained from Afrox Ltd South Africa. The RPMI medium, fetal bovine serum, and horse serum (Sigma-Aldrich, St Louis, MO, USA) and other reagents used were all of analytical grade.

\section{Production of carbon nanotubes}

The modification of the chemical vapour deposition (CVD), termed the swirled floating catalyst (SFCCVD $)^{18}$ was used to produce the $p$-MWCNTs. It consists of a vertical silica plug flow reactor that is immersed in a furnace connected to a temperature regulator with valves, rotameter and a pressure controller. The CNTs were produced by the catalytic decomposition of acetylene in argon gas flow using ferrocene as the catalyst. The production was carried out at a reactor temperature range of $700-900{ }^{\circ} \mathrm{C}$ and ferrocene heated at $150 \mathrm{U} C$ for $1 \mathrm{~h}$ reaction time using acetylene with flow rate of $100 \mathrm{ml} / \mathrm{min}$. The transmission electron microscopy(TEM, JEOL JEM-100S), scanning electron microscopy (SEM), Brunauer-Emmett-Teller (BET, Micromeritics Tristar), Raman spectroscopy, and Thermogravimetric analysis (TGA, Perkin Elmer TGA 4000 Thermogravimetric Analyser) were used to characterise the synthesized CNTs.

\section{Functionalization of carbon nanotubes.}

The pristine MWCNTs (p-MWCNTs) were oxidised using $\mathrm{H}_{2} \mathrm{SO}_{4} / \mathrm{HNO} 3$ in a $3: 1(\mathrm{v} / \mathrm{v})$ and $30 \% \mathrm{HNO}_{3}$ acids to create the carboxylic groups $(-\mathrm{COOH})$ by sonication. The solution was then filtered and washed several times with distilled water to remove residual acids ( $\mathrm{pH}$ neutal) and then dried at $50^{\circ} \mathrm{C}$ in an oven. The oxidation procedure modifies the $p$-MWCNTs surfaces with carboxylic groups resulting into MWCNT-COOH (figure. 1), which are required for further coupling ${ }^{4}$. The 0 -MWCNTs were then sterilely (filtration) and serially (10-fold dilution) diluted in RPMI medium in a biosafety cabinet and sonicated as stock solution.

\section{PC12 neuronal cell culture}

PC12 cells (obtained from the Department of Pharmacy and Pharmacology, University of the Witwatersrand, South Africa) were maintained in RPM1 medium supplemented with $10 \% \mathrm{v} / \mathrm{v}$ donor horse serum, $5 \% \mathrm{v} / \mathrm{v}$ fetal bovine serum and $1 \% \mathrm{v} /$ $\mathrm{v}$ PenStrap (penicillin and streptomycin). All cells were cultured in plastic culture flasks at 37ÚC in a $5 \% \mathrm{CO}_{2}$ humidified incubator (HERA Cell, Thermo Electron Corporation).

\section{Cell-viability}

A CytoTox-Glo assay was used to measure cell viability. All samples were sterilized for $24 \mathrm{~h}$ under UV irradiation. The PC12 cells were seeded in each well containing $0,50,100$ and $200 \mu \mathrm{g} / \mathrm{ml}$ of $o_{-}^{-}$ MWCNTs. They were then incubated at $0,2,4,22$ and $24 \mathrm{hr}$.

\section{Cytotoxicity of carbon nanotubes towards PC- 12 neuronal cells}

To determine the cytotoxicity of CNTs in PC-12 neuronal cells, the CytoTox-Glo ${ }^{\mathrm{TM}}$ Promega assay (Madison, USA) was used according to the manufacturer's instructions (Niles et al 2007).

In a 96-well plate, cells were prepared by adding $12 \mu \mathrm{l}$ of PC12 cell culture to each well in triplicates. Twelve microliter of freshly prepared sterile media containing CNTs (containing 2, 50, 100 and 200 $\mu \mathrm{g} / \mathrm{ml}$ of 0 -MWCNTs) were then added to the $96-$ well plates containing cells. The cells were then added and cultured for not more than $24 \mathrm{hr}$, as recommended by the manufacturer. After 2, 4, 22 and $24 \mathrm{hr}$ of incubation $12.5 \mu \mathrm{l}$ of CytoTox-Glo Cytotoxicity Reagent was added to all wells. The 96-well plate was then taken to the Victor X3 and mixed by orbital shaking for about 30 seconds and incubated at room temperature for $15 \mathrm{~min}$. The luminescence was then measured onVictor X3 (PerkinElmer) and recorded (representing signal obtained from dead cells). $12.5 \mu$ l of lysis reagent (Assay kit) was then added to each and mixed again by orbital shaking for 30 seconds and incubated at room temperature for 15 minutes. The Luminescence 
was recorded again on Victor X3 (Signal obtained from total cell population). This procedure was repeated at 4, 22 and $24 \mathrm{hr}$ incubation, to obtain the luminescent contribution to viable cells.

Morphometric analysis of PC12 cells

Cells were placed onto a glass slide using a micropipette and covered with a cover slip before viewing. The morphology of PC12 cells after treatment was studied under a bright field microscope (Olympus Optical CO. Ltd, Tokyo, Japan).

\section{Statistical Analyses}

Statistical analyses were performed using the analysis of variance (One-Way ANOVA) to compare between the triplicates and Student T-test to compared between p-MWCNTs and o-MWCNTs using the Origin 6.0 Professional software and was considered statistically significant $p<0.05$. All the experiments were done in triplicates and data shown as mean $\pm \mathrm{SD}$.

\section{Ethics Clearance}

The proposed study was submitted for ethical consideration and approval by the University of the Witwatersrand Research Ethics Committee.

\section{Results}

Figure 1 shows the creation of the 0 -MWCNTs from p-MWCNTs and how carboxyl (-COOH) groups are aligned on the $o$-MWCNTs. The o-MWCNTs in this case is known as functionalized MWCNT with carboxylic ends (MWCNT-COOH).

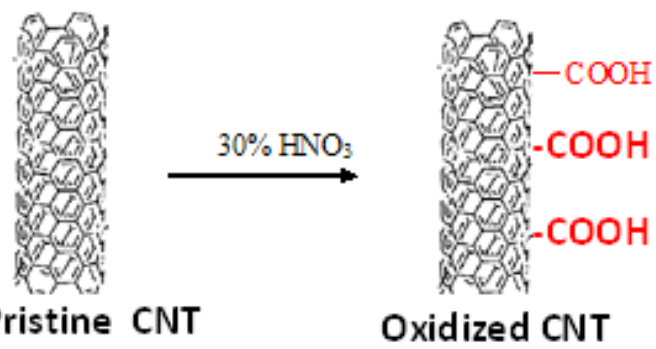

Figure 1: Oxidation of pristine MWCNT to create MWCNT-COOH

The o-MWCNTs and p-MWCNTs morphologies were viewed using the TEM and SEM. The TEM micrograph structures of $p$-MWCNTs are shown in figure. $2 \mathrm{a}$, while those of the 0 -MWCNTs $(1: 3$ $\mathrm{HNO}_{3}: \mathrm{H}_{2} \mathrm{SO}_{4}$ and $30 \% \mathrm{HNO}_{3}$ acids) are shown in figures $2 \mathrm{~b}$ and $2 \mathrm{c}$. Figure $3 \mathrm{a}$ shows the SEM micrograph of $p$-MWCNTs while Figure $3 \mathrm{~b} 30 \%$ $\mathrm{HNO}_{3}$ oxidized and figure $3 \mathrm{c} 1: 3 \mathrm{HNO}_{3}: \mathrm{H}_{2} \mathrm{SO}_{4}$ oxidized MWCNTs. Both the $p$-MWCNTs and oMWCNTs sizes ranged from $53 \pm 12 \mathrm{~nm}$ in diameter and length of $2.5 \pm 0.5 \mu \mathrm{m}$.
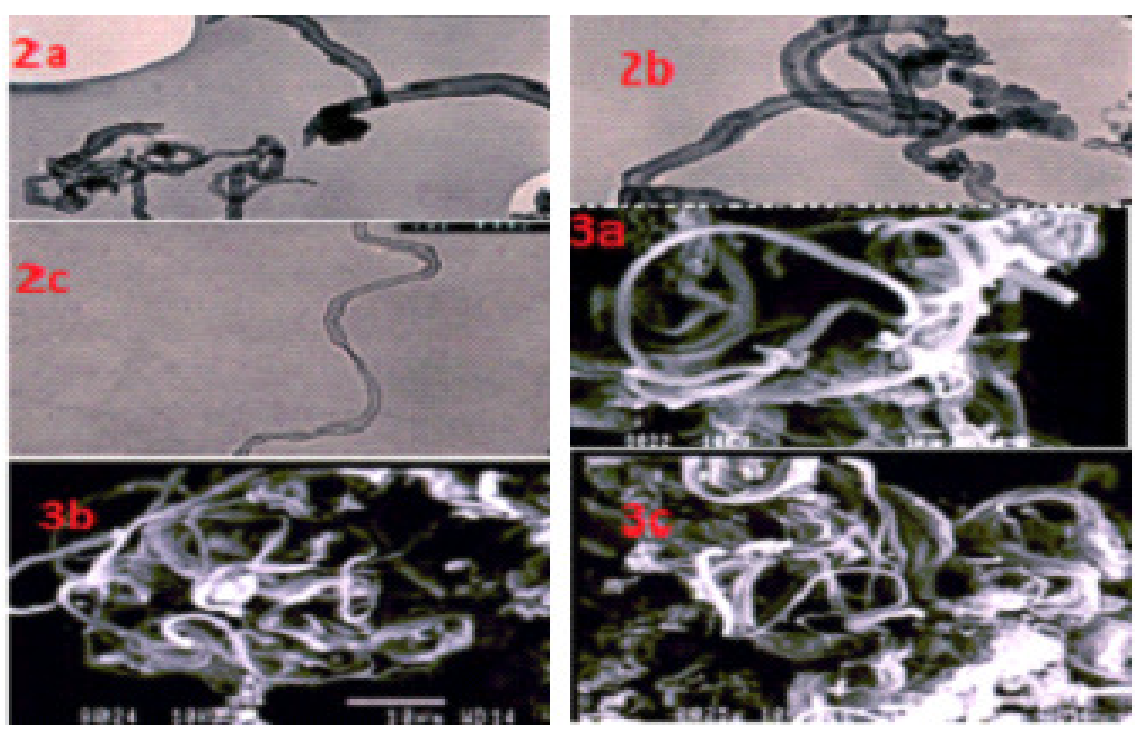

Figure 2a: TEM micrograph of pristine MWCNTs, 2b: Oxidized MWCNTs after1:3 $\mathrm{HNO}_{3}: \mathrm{H}_{2} \mathrm{SO}_{4}$ acid treatment and 2c: $30 \% \mathrm{HNO}_{3}$ oxidized MWCNTs.

Figures 3a: SEM Micrograph of $p$ - MWCNTs, 3b: 30\% $\mathrm{HNO}_{3}$ oxidized and 3c: 1:3 $\mathrm{HNO}_{3}: \mathrm{H}_{2} \mathrm{SO}_{4}$ oxidized MWCNTs. 
The Brunauer-Emmett-Teller (BET) analysis of the various MWCNT are shown in table 1. The surface areas (SA) ranged from $29.5-36.0 \mathrm{~m}^{2} / \mathrm{g}$, average pore volume $\left(0.1-0.16 \mathrm{~cm}^{2} / \mathrm{g}\right)$ and average pore diameter of pristine (13.4-20.6nm).

The Raman spectroscopy analysis of the pristine, $30 \% \mathrm{HNO}_{3}$ and $1: 3 \mathrm{HNO}_{3}: \mathrm{H}_{2} \mathrm{SO}_{4}$ treated MWCNTs are shown in table 2 . The band positions were found to range from $1321 \mathrm{~cm}^{-1}-1327 \mathrm{~cm}^{-1}$ with ID/IG ration of $30 \% \mathrm{HNO}_{3}$ treated MWCNTs at 1.01 while that of pristine 1.03 and $1: 3 \mathrm{HNO}_{3}: \mathrm{H}_{2} \mathrm{SO}_{4}$ at 1.39 .

Table 1: BET results of MWCNTs
The TGA analysis was employed to determine the quality $^{19}$ and chemical stability of MWCNTs and to estimate the amount of residual catalyst present in the sample before and after oxidation/purification ${ }^{20}$. The TGA curves of $p$-MWCNTs, $30 \% \mathrm{HNO}_{3}$ and 1:3 $\mathrm{HNO}_{3}: \mathrm{H}_{2} \mathrm{SO}_{4}$ acid treated MWCNTs are represented in Figure. 4. The $p$-MWCNTs were found to decompose easily and reported the highest value of metal catalyst (13.20\%). The 30\% $\mathrm{HNO}_{3}$ oxidation showed $9.70 \%$ while $1: 3 \mathrm{HNO}_{3}: \mathrm{H}_{2} \mathrm{SO}_{4}$ reported catalyst impurities of $11.67 \%$. Thus the $30 \%$ $\mathrm{HNO}_{3}$ treatment removed more metal catalysts than the $1: 3 \quad \mathrm{HNO}_{3}: \mathrm{H}_{2} \mathrm{SO}_{4}$. Thermal stability of MWCNTs depend on the side wall "defects" and the amount of metallic impurities.

\begin{tabular}{lllc}
\hline Sample & SA $\left(\mathbf{m}^{2} / \mathbf{g}\right)$ & $\begin{array}{l}\text { Average pore } \\
\text { volume }\left(\mathbf{c m}^{3} / \mathbf{g}\right)\end{array}$ & $\begin{array}{l}\text { Average pore } \\
\text { diameter }(\mathbf{n m})\end{array}$ \\
\hline Pristine MWCNTs & 31.6 & 0.16 & 20.6 \\
$30 \% \mathrm{HNO}_{3}$ treated MWCNTs & 36.0 & 0.16 & 17.3 \\
$1: 3 \mathrm{HNO}_{3}: \mathrm{H}_{2} \mathrm{SO}_{4}$ & 29.5 & 0.10 & 13.4 \\
\hline
\end{tabular}

Table: 2 Raman spectra results of pristine, $30 \% \mathrm{HNO}_{3}$ and 1:3 $\mathrm{HNO}_{3}: \mathrm{H}_{2} \mathrm{SO}_{4}$ MWCNTs treated

\begin{tabular}{|c|c|c|c|c|c|c|c|}
\hline \multirow[t]{2}{*}{$\begin{array}{l}\text { Sample } \\
\text { intensity }\end{array}$} & \multicolumn{2}{|c|}{$\begin{array}{l}\text { Band position } \\
\text { Intensity ratio }\end{array}$} & \multicolumn{2}{|c|}{$\begin{array}{l}\text { Band position } \\
\text { Band width }\end{array}$} & \multicolumn{2}{|c|}{$\begin{array}{l}\text { Band intensity } \\
\text { Band width }\end{array}$} & \multirow{2}{*}{$\begin{array}{c}\text { B a n d } \\
G\end{array}$} \\
\hline & D1 & G & ID & IG & ID/IG & D1 & \\
\hline Pristine MWCNTs & 1324 & 1587 & 37 & 36 & 1.03 & 194 & 75 \\
\hline $\begin{array}{l}30 \% \mathrm{HNO}_{3} \text { acid treated } \\
\text { MWCNTs }\end{array}$ & 1321 & 1584 & 72 & 71 & 1.01 & 182 & 74 \\
\hline $\begin{array}{l}\text { 1:3 } \mathrm{HNO}_{3}: \mathrm{H}_{2} \mathrm{SO}_{4} \text { acid treated } \\
\text { MWCNTs }\end{array}$ & 1327 & 1582 & 36 & 26 & 1.39 & 159 & 97 \\
\hline
\end{tabular}

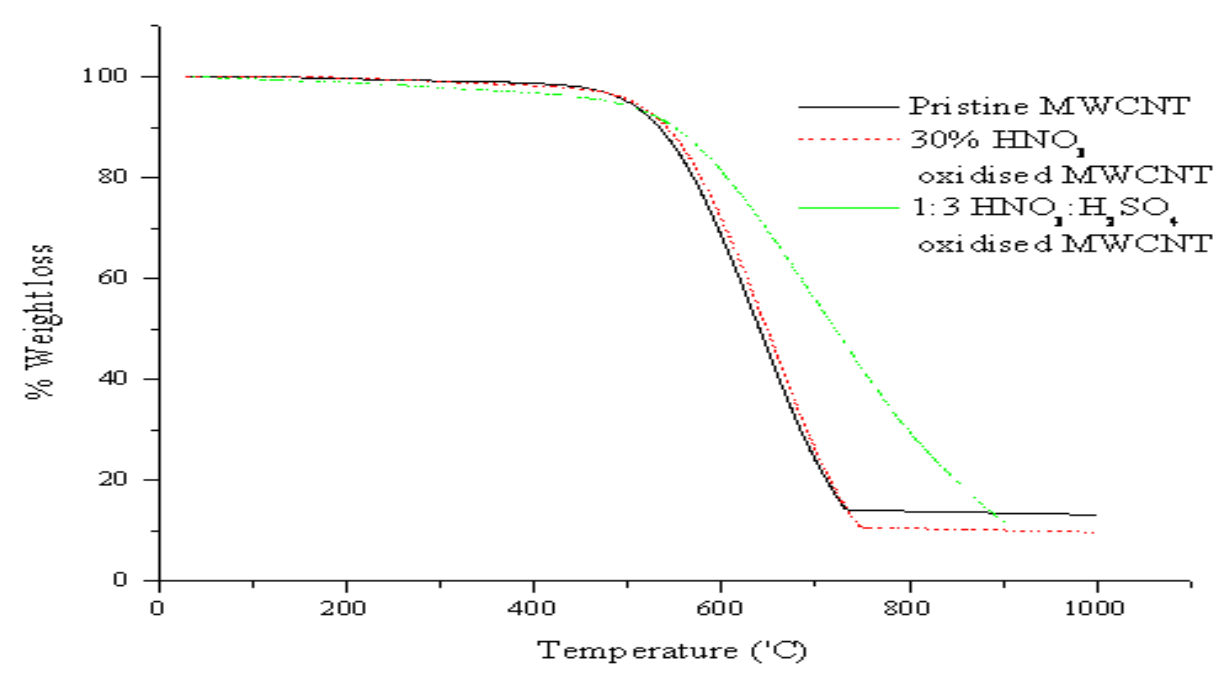

Figure 4: Thermal stability of pristine, $30 \% \mathrm{HNO}_{3}$ and 1:3 $\mathrm{HNO}_{3}: \mathrm{H}_{2} \mathrm{SO}_{4}$ oxidised MWCNTs 
The undifferentiated PC12 cells were used to evaluate the cell viability of $30 \% \mathrm{HNO}_{3}$ as shown in Figure 5. The $30 \% \mathrm{HNO}_{3}$ o-MWCNTs was used because of the purity when compared to $p$-MWCNTs and $1: 3 \mathrm{HNO}_{3}: \mathrm{H}_{2} \mathrm{SO}_{4}$ acid treated. There was a no significant difference between the $p$-MWCNTs and o-MWCNTs $(\mathrm{p}<0.05)$.

In this study the Promega assay was utilized to determine the effect of various concentrations of o-MWCNTs on the viability of cultured PC12 cells as shown in figure 5. After 2 hours of incubation, the $50 \mu \mathrm{g} / \mathrm{ml}$ o-MWCNTs resulted in no loss in cell viability whilst after $4 \mathrm{hr}$ of incubation the percentage of viable cells was reduced to $79 \%$ as compared to the control group (incubated with no MWCNTs). The $100 \mu \mathrm{g} / \mathrm{ml}$ and $200 \mu \mathrm{g} / \mathrm{ml}$ o-MWCNT showed a reduction in cell viability from 84 and 61\% respectively in 2 hours when compared to the control group. After 4 hours the reduction in viability was observed in all the 3 concentrations (50, 100 and $200 \mu \mathrm{g} / \mathrm{ml}$ ). The cells were found to recover at longer period times of incubation. At 22 hours, $87 \%$ of the cells in 50 to $200 \mu \mathrm{g} / \mathrm{ml}$ o-MWCNT concentrations recovered when compared to the control groups. The recovery was found to increase up to 24 hours of incubation with no loss in cell viability. The effect of high concentrations of 0 MWCNTs on the viability of PC12 cells was found suppressive only at earlier periods of incubation and this suppressive effect was concentration dependent. This indicates that at shorter (2 and 4hours) incubation in o-MWCNTs affect PC12 cells while at longer period, regeneration can occurs due to adaptation in the $o$-MWCNTs.

To examine the morphology of PC12 cells, a bright field microscope was used, figure 6 (a)-(b). Figure 6 a shows the cells cultured without MWCNTs while Figure 6b shows a typical image of PC12 cells cultured with o-MWCNTs .The microscopic observation showed that the PC12 cells grew and spread with the 0 -MWCNTs by adhering to the $o$ MWCNTs (figure 6b). The untreated cells exhibited normal growth with organized cellular structures (figure 6a).

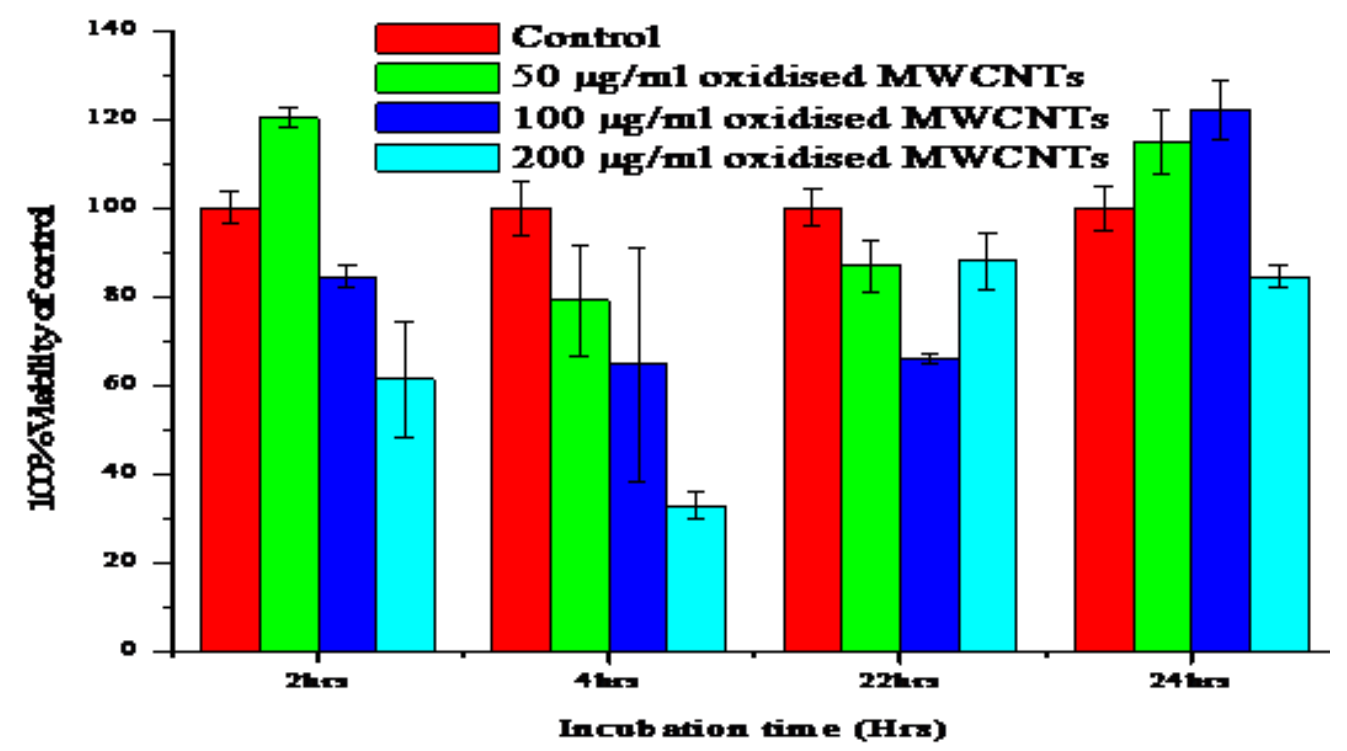

Figure 5: The response effect of PC12 cells to oxidised MWCNTs. Error bars represent standard deviation (SD) of one set of triplicate data

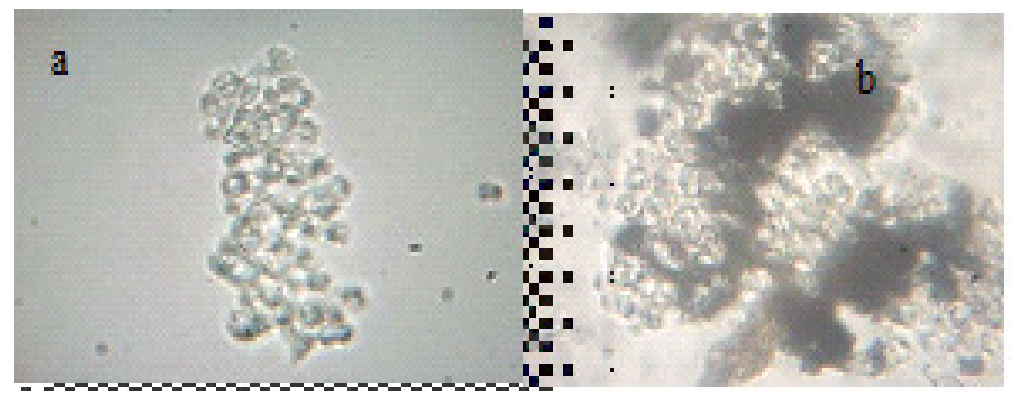

Figure 6: Optical phase contrast microscope photographs of PC12 cells (6a) incubated without oxidized MWCNTs (6b) incubated with oxidized MWCNTs 


\section{Discussion}

The synthesis of $p$-MWCNTs are widely reported in literature with varied diameters and lengths ${ }^{1,18}$ as well as o-MWCNTS ${ }^{2}$. The results obtained were similar to those earlier reported by Abdulkareem et $\mathrm{al}^{21}$ and Yah et $\mathrm{al}^{22}$ with similar diameters. The SEM images of the $p$-MWCNTs and $o$-MWCNTS are shown in Figures.3a-c with length distribution of $1 \pm$ $0.5 \mu \mathrm{m}$. The 0 -MWCNTs showed different degrees of oxidation with shorter lengths as compared to the $p$-MWCNTs. These results were similar to those reported by Cheng et $\mathrm{al}^{20}$ who showed the oxidation MWCNTs with $1: 3 \mathrm{v} / \mathrm{v} \mathrm{HNO}_{3}: \mathrm{H}_{2} \mathrm{SO}_{4}$ acid. However, their lengths and sizes $(500 \mathrm{~nm}$ to $5 \mu \mathrm{m}$ and $940-974 \mathrm{~nm}$ ) were by far greater than those reported in this study $(1 \pm 0.5 \mu \mathrm{m}$ and $53 \pm 12 \mathrm{~nm})$ which may have resulted from the sonication process. The sonication process may lead to destruction of the conjugate bonds on the 0 -MWCNTS as well as preventing aggregation and agglomeration ${ }^{4}$.

There was no significant difference between the surface area of the $p$-MWCNTS and $o$ MWCNTS. Though the surface area was not as large as those reported by Bacsa et $\mathrm{al}^{23}$, it was sufficient enough for analysis.

The Raman spectra differed from those reported by Bacsa et $\mathrm{al}^{23}$ and Yah et $\mathrm{al}^{18}$ with higher proportion of tubular carbon. However there was a no significant difference between the $p$-MWCNTs and $o$-MWCNTs $(p<0.05)$ because the $\mathrm{p}$-MWCNTS and o-MWCNTS ID/IG ratio were closer to 1 . The determination of the purity of the o-MWCNTS showed $30 \% \mathrm{HNO}_{3}$ acid oxidation the most applicable method similar to that reported by Phillips et $\mathrm{al}^{2}$, Dettlaff-Weglikowska et $\mathrm{al}^{24}$ and Kim et $\mathrm{al}^{25}$.

Reports on functionalized MWCNTs toxicity pro-file on neuronal cells are limited. In this study we reported the effect $o$-MWCNTs on PC12 neuronal cells. The findings demonstrate that high $(100 \mu \mathrm{g} / \mathrm{ml}$ and $200 \mu \mathrm{g} / \mathrm{ml})$ concentrations of 0 MWCNTs can inhibit PC12 cells proliferation when compared to lower $(50 \mu \mathrm{g} / \mathrm{ml})$ concentrations. These were similar to those reported by Bang et $\mathrm{al}^{26}$ that at sufficiently high concentrations, MWCNTs can inhibit reduced PC12 viability. According to reports by Meng et $\mathrm{al}^{27}$ short exposure of MWCNTs to neuronal cells can lead to up-regulation and expression of neurotrophin pathways with unknown underlying mechanism. Earlier reports by Xu et al ${ }^{14}$ showed that carboxyl-terminated MWCNTs can antagonize the 3 types of potassium channels on undifferentiated PC12 cells. However the potassium channels cell alteration had no significant effect in the generation of reactive oxygen species (ROS) ${ }^{14}$. The ROS may not have been involved in the potassium suppression but the elemental suppression can give a huge impact on neurone electrical impulse transmission and excitation processes ${ }^{14}$.

Since the inhibition of the PC12 cells was found to be dose dependent and at longer incubation period could recover has been observed in similar earlier reports ${ }^{11,14}$. This phenomenon has been reported by Cheng et a $\mathrm{l}^{11}$ that shorter exposure time of $0.01 \mathrm{mg} / \mathrm{ml}$ of $o-M W C N T s$ on endothelial cells can cause a slight reduction in cells viability and at longer period a huge cells recovery. This was supported by Xu et al ${ }^{14}$ that MWCNT-COOH are time-dependent on PC12 cells but can be irreversible as well. Furthermore Wang et $\mathrm{al}^{15}$ reported that long and short pristine SWCNTs can cause decrease in PC12 cells viability which are time and dose dependent arising from oxidative stress to nervous system due to neuronal cells injuries. The bright field morphological structures of o-MWCNTs on PC12 cells (Figures $6 \mathrm{a} \& 6 \mathrm{~b}$ ) showed that of 0 -MWCNTs has no effect on PC12 cells. They were found to be internalized in the PC12 cells. The bright field micrographs results were similar to those reported by Raffa et $\mathrm{al}^{28}$ where $o$-MWCNTs was found to internalize in PC12 cells. Although this can be influence by the size and length of the $0-\mathrm{MWCNTs}{ }^{28}$. However, the mechanism of o-MWCNT penetration into PC12 cells is yet to be elucidated and the more information needed to augment 0 MWCNTs PC12 cells toxicity. The induction of PC12 cell viability according to the findings by Meng et $\mathrm{al}^{27}$ Iron (Fe) impurities embedded in the 0 MWCNTs during the production process can be responsible for the PC12 induction. Therefore, the dynamics of $o$-MWCNTs cellular involvement in PC12 toxicity and safe applications need further studies.

\section{Conclusion}

The quality of purified MWCNTs resulting from the $30 \% \mathrm{HNO}_{3}$ acid treatment was higher than that of $1: 3 \mathrm{HNO}_{3}: \mathrm{H}_{2} \mathrm{SO}_{4}$ acid treated MWCNTs. The response of 0 -MWCNTs in the PC12 cells was both concentration and time dependent. PC12 cells inhibition was observed at shorter incubation period (2-4 hours). However, at long exposure periods (2224 hours) there was massive cells recovery in the present of o-MWCNT doses. Generally the oMWCNTs in-vitro toxicity studied in PC12 cells 
showed very minimal adverse effect but their use in biomedical applications need further safety investigation as well as mechanism of cell recovery at longer periods of exposure.

\section{Acknowledgements}

The authors are grateful for the financial support from the National Research Foundation (NRF) of South Africa and NRF Focus Area, Nanotechnology flagship programme, DST/NRF Centre of Excellence. The student bursaries provided by the Wits University are much appreciated.

\section{References}

1. Mamvura TA, Iyuke SE, Sibanda V, Yah CS. Immobilisation of yeast cells on carbon nanotubes. South African Journal of Science, 2012; 108(7/8): Art \#768.

2. Phillips CL, Yah CS, Iyuke SE, Rumbold K, Pillay V. The cellular response effect of Saccharomyces cerevisiae in Multi-Walled Carbon Nanotubes (MWCNTs). Journal of Saudi Chemical Society, 2012; doi:101016/jjscs201201005.

3. Bianco A, Kostarelos K, Prato M. Applications of carbon nanotubes in drug delivery. Current Opinion in Chemical Biology, 2005; 9(6) : 674-679.

4. Ngoy JM, Iyuke SE, Neuse WE, Yah CS. Covalent Functionalization for Multi-Walled Carbon Nanotube (o-MWCNT) -Folic Acid bound bioconjugate. Journal of Applied Sciences 2011;11(15): 2700-2711.

5. Cherukuri P, Bachilo SM, Litovsky SH, Weisman RB. Near-infrared fluorescence microscopy of single-walled carbon nanotubes in phagocytic cells Journal of the American Chemical Society, 2004; 126(48): 15638-15639.

6. Shvedova AA, Kisin ER, Porter D, Schulte P, Kagan VE, Fadeel B, Castranova V. Mechanisms of pulmonary toxicity and medical applications of carbon nanotubes: Two faces of Janus? Pharmacology \& therapentics, 2009; 121 (2): 192-204.

7. Wu XZ, Chang WQ, Cheng AX, Sun LM, Lou, HX. Plagiochin E, an antifungal active macrocyclic bis(bibenzyl), induced apoptosis in Candida albicans through a metacaspase-dependent apoptotic pathway. Biochimica et biophysica acta, 2010; 1800(4):439-447.

8. Gilmore JL, Yi X, Quan L, Kabanov AA. Novel Nanomaterials for Clinical Neuroscience $J$ Neuroimmune Pharmacol 2008; 3(2): 83-94.
9. Sucapane A, Cellot G, Praton M, Giugliano M, Parpura V, Ballerini L. Interactions Between Cultured Neurons and Carbon Nanotubes: a Nanoneuroscience Vignette. Journal of Nanoneuroscience, 2008;1: 1-7.

10. Warheit DB, Laurence BR, Reed KL, Roach DH, Reynolds GA, Webb TR. Comparative pulmonary toxicity assessment of single-wall carbon nanotubes in rats. Toxicological ScienIces: An official journal of the Society of Toxicology, 2004;77(1): 117-125.

11. Cheng, X Zhong, J Meng, J Yang, M Jia, F Xu, Z Kong, H Xu, H 2011 Characterization of multi walled carbon nanotubes dispersing in water and associateion with biological effects Journal of Nanomaterials Doi :101155/2011/938491.

12. Yah CS, Simate GS, Iyuke SE. Nanoparticles toxicity and their routes of exposures PaksJPS: 2012 ; 25(2): 477-491.

13. Walkinshaw G, Waters CM. Nuerotixin-induced cell death in neuronal PC12 cells is mediated by induction of apoptosis. Nueroscience, 1994; 63(4): 975-987.

14. Xu H, Bai J, Meng J, Hao W, Xu H, Cao J-M. Multi-walled carbon nanotubes suppress Potassium channel activities in PC12 cells. Nanotechnology 2009; 20: 285102 (9pp).

15. Wang J, Sun P, Bao Y, Liu J, An L. Cytotoxicity of single-walled carbon nanotubes on PC12 cells. 2011; :Toxicology in Vitro 25 : 242-250

16. Zhang T, Xu M, He L, Xi K, Gu M, Jiang Z. Synthesis, characterization and cytotoxicity of phosphoryl choline-grafted water-soluble carbon nanotubes Carbon, 2008; 46(13): 1782-1791.

17. Bottini M, Bruckner S, Nika K, Bottini N, Bellucci S, Magrini A, Bergamaschi A, Mustelin T. Multiwalled carbon nanotubes induce $\mathrm{T}$ lymphocyte apoptosis Toxicology letters, 2006; 160(2): 121-126.

18. Yah CS, Iyuke SE, Simate GS, Unuabonah EI, Bathgate G, Matthews G, Cluett JD. Continuous synthesis of multiwalled carbon nanotubes from xylene using the swirled floating catalyst chemical vapor deposition technique. Journal of Materials Research, 2011; b 26 (5): 623 -632.

19. Mansfiled E, Kar A, Hooker SA. Applications of TGA in quality control of SWCNTs. Analytical and Bioanlytical Chemistry, 2010; 396(3): 1071-1077

20. Cheng C, Müller KH, Koziol KKK, Skepper JN, Midgley PA, Welland ME, Porter AE. Toxicity and imaging of multi-walled carbon nanotubes 
in human macrophage cells Biomaterials, 2009; 30(25):4152-4160

21. Abdulkareem AS, Afolabi AS, Iyuke SE, Pienaar, HC. Synthesis of carbon nanotubes by swirled floating catalyst chemical vapour deposition method Journal of Nanoscience and Nanotechnology, 2007; 7(9) : 3233-3238.

22. Yah CS, Simate GS, Moothi K, Maphuta S. a Synthesis of large carbon Nanotubes from Ferrocene: The Chemical Vapour Deposition Technique. Trends in Applied Sciences Research, 2011; (11): 1270-1279.

23. Bacsa RR, Laurent $\mathrm{CH}$, Peigney A, Bacsa WS Vaugien TH, Rousset A. High specific surface area carbon nanotubes from catalytic chemical vapour deposition process Chemical Physical Letter, 2002; 323: 566-571.

24. Dettlaff-Weglikowska U, Benoit JM, Chiu P, Graupner R, Lebedlin S, Roth S. "Chemical functionalization of single walled carbon nanotubes" Current Applied Physics. 2002; 2: 497 $-501$.

25. Kim Y, Cho J, Ansari SG, Kim H, Dar MA, Seo H, Kim G, Lee D, Khang G, Shin H. Immobilization of avidin on the functionalized carbon nanotubes. Synthetic Metals. 2006; 156(1415): 938-943.

26. Bang J, Yeyeodu S, Gilyazova N, Witherspoon S, Ibeanu G. Effects of Carbon Nanotubes on a Neuronal Cell Model In Vitro. Atlas Journal of Biology. 2011; 1 (3): 70-77, 2011

27. Meng L, Chen R, Jiang A, Wang L, Wang P, Li CZ, Bai R, Zhao Y, Autrup H, Chen C. Short Multiwall Carbon Nanotubes Promote Neuronal Differentiation of PC12 Cells via UpRegulation of the Neurotrophin Signaling Pathway. Small, 2013; 9(9-10):1786-98.

28. Raffa V, Ciofani G, Nitodas S, Karachalios T, D’Alessandro D, Masini M, Cuschieri A. Can the properties of carbon nanotubes influence their internalization by living cells? Carbon 2008; 4 6: $1600-1610$ 